Diabetologia 11, 113-117 (1975)

(c) by Springer-Verlag 1975

\title{
Inhibition of Bile Salt Absorption by Blood-Sugar Lowering Biguanides
}

\author{
W. F. Caspary and W. Creutzfeldt \\ Division of Gastroenterology and Metabolism, Department of Medicine, University of Göttingen, Federal Republic of Germany
}

Received: September 20, 1974, and in revised form: December 11, 1974

Summary. The effect of blood sugar lowering biguanides (phenethyl-, butyl- and dimethylbiguanide) upon jejunal and ileal transport of bile salts (tauro- and glycocholate) was tested in rat small intestine by an in vitro technique. Biguanides inhibited active transport of bile salts in the ileum, but did not affect diffusional absorption of bile salts in the jejunum. The inhibitory effect was time-dependent and not reversible under in vitro incubation conditions, suggesting that biguanides must enter intestinal mucosal cells in order to exert their inhibitory action on active transport of glucose analogues, amino acids, calcium and bile salts. Since biguanides achieve high tissue concentrations in the small intestine even after parenteral administration, inhibition of ileal bile salt reabsorption by biguanides could possibly explain the lipid- and cholesterol-lowering effect of these oral antidiabetic drugs.

Key words: Bile salt absorption, biguanides, phenformin, buformin, metformin, active transport, bile salt malabsorption.
The mechanism of the blood sugar lowering action of bigunanides is not completely understood $[3,20$, 22, 26]. An insulin-potentiating effect of biguanides upon glucose uptake by muscle $[8,9]$, inhibition of gluconeogenesis in the liver $[1,3,16,17,20,23,36]$ and inhibition or delay of intestinal absorption $[2,3$, $4,6,7,11,12,13,30,21,27,29,30,41]$ have been considered as the possible mechanism. Biguanides inhibit intestinal absorption of sugar in vitro $[11,27$, $29,30,41]$ and in vivo $[2,6,7,21]$, active transport of amino acids $[12,13]$ and calcium $[12,20]$ in vitro as well as vitamin $\mathrm{B}_{12}$-absorption in patients on metformin $[4,5,20,37,38]$ and phenformin [38]. The latter observation together with the findings of an increase of stool weight [4] and frequency [31], a slightly increased faecal fat excretion [4] and a lowering of serum cholesterol $[3,4,19,25,26,32,34$, 35] suggests that biguanides might affect transport processes confined to the distal small intestine. Since active transport of bile acids, in contrast to sugar and amino acid absorption, is confined to the ileum [24, 28], the effect of biguanides upon the active transport of bile acids in rat ileum has been examined by an in vitro technique.

\section{Material and Methods}

\section{Materials}

${ }^{3} \mathrm{H}-\mathrm{Na}$-taurocholate was obtained from New England Nuclear, ${ }^{14}$-C-glycyl-cholic acid from The Radiochemical Centre, Amersham. Taurocholate (Serva, Heidelberg) and glycocholate (Serva, Heidelberg) contained less than $0.1 \%$ impurities as previously reported $[14,15]$. Phenethylbiguanide was supplied by Hoechst Pharmaceutical Company, FrankfurtHoechst, butylbiguanide was kindly supplied by Dr. R. Beckmann (Chemie Grünenthal, Stolberg, Rhld.) and dimethylbiguanide was provided by Dr. H. Haury, München.

\section{Bile Acid Transport Technique}

Female, Wistar rats $(120 \pm 10 \mathrm{~g})$ were kept on a lab chow diet and fasted overnight with free access to water before the experiments were performed. Intestinal transport of bile salts was measured with the tissue accumulation technique of Crane and Mandelstam [18] and the everted sac technique of Wilson and Wiseman [40] with modifications as reported earlier $[11,12,15]$. Small intestinal tissue $15 \mathrm{~cm}$ proximal to the ileocecal valve was considered to represent ileum; intestinal segments $35-50 \mathrm{~cm}$ past the pylorus are referred to as 'mid-intestine' (= jejunum). 200-300 $\mathrm{mg}$ wet weight of tissue were incubated in Erlenmeyer flasks with $10 \mathrm{ml}$ Krebs-Henseleit phosphate buffer under pure oxygen and the appropriate additions of substrate and biguanides. The serosal compartment of the everted sacs, measuring $7 \mathrm{~cm}$ in length, was filled with $0.5 \mathrm{ml}$ of the same medium used on the mucosal side. The incubation medium contained tauro- or glycocholate at a concentration of $0.2 \times 10^{-3} \mathrm{M}$ and labelled ${ }^{8} \mathrm{H}-\mathrm{Na}$-taurocholate or ${ }^{14} \mathrm{C}$-glycocholate to give $50000-100000 \mathrm{dpm} / 5 \mathrm{ml}$ incubation medium.

Results are expressed as:

per cent filling $=100 \times \frac{\mu \text { moles } / \mathrm{ml} \text { tissue water }}{\mu \text { moles } / \mathrm{ml} \text { mucosal medium }}$ assuming a tissue water content of $80 \%$ of the tissue wet weight $[10,15,18]$. Extracellular space corrections were performed by the use of ${ }^{3} \mathrm{H}$ - or ${ }^{14} \mathrm{C}-\mathrm{D}$ - 
mannitol [10]. In everted sac experiments results are expressed as serosal/mucosal (S/M) concentration ratio [40]. A value of $>100 \%$ filling or a $\mathrm{S} / \mathrm{M}$-ratio $>1$ means accumulation of the substrate either in the tissue or in the serosal compartment against a concentration gradient.

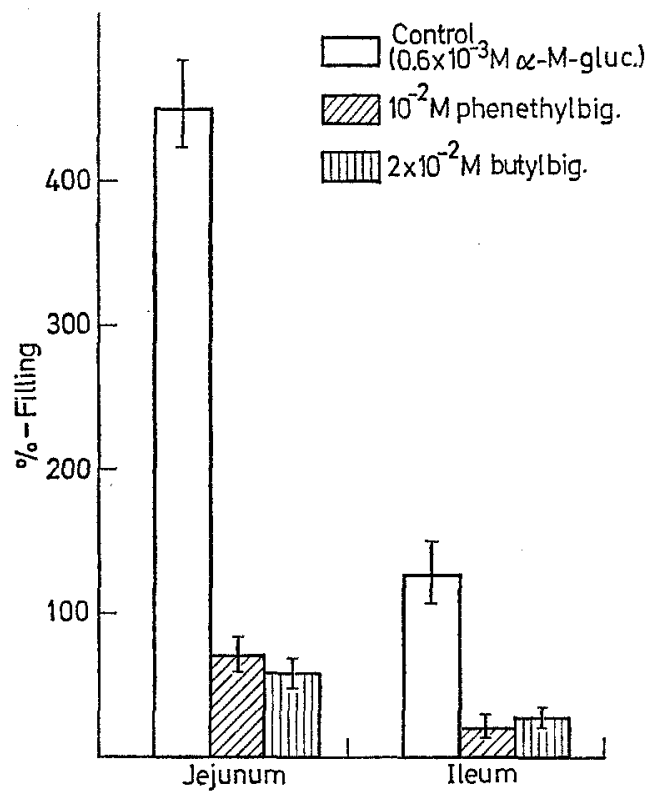

Fig. 1. Inhibitory effect of biguanides upon active transport of $\alpha$-methyl-glucoside in rat jejunum and ileum. Segments of rat small intestinal tissue were incubated for $30 \mathrm{~min}$ with $\alpha$-methyl-glucoside $\left(0.6 \times 10^{-3} \mathrm{M}\right)$ in presence and absence of phenethyl- and butylbiguanide. Results are means \pm SEM $(\mathrm{n}=7)$
Results are presented as means \pm SEM. Statistical analyses were performed using the student $t$-test.

\section{Results}

In order to compare the effect of biguanides upon jejunal and ileal active transport processes tissue uptake of an actively transported glucose analogue, $\alpha$ methyl-glucoside, was measured in the presence of biguanides by jejunal and ileal small intestine (Fig. 1). Phenethyl- and butylbiguanide inhibited active transport of the non-metabolizable $\alpha$-methyl-glucoside in the ileum and the jejunum. $\alpha$-methyl-glucoside was accumulated to a much higher degree in the jejunum than in the ileum (Fig. 1). Tissue uptake of conjugated bile salts (tauro-and glycocholate) occurred in the ileum against a concentration gradient, whereas minimal absorption took place in the jejunum by the mechanism of ionic and nonionic diffusion [24, 28] (Fig. 2). Biguanides (phenethyl-, butyl- and dimethylbiguanide) markedly inhibited active transport of bile salts in the rat ileum but did not affect the diffusional process in the jejunum (Fig. 2).

The onset of the inhibitory effect was observed 5 min after incubation by the simultaneous addition of substrate and biguanides (Fig. 3). The inhibitory effect increased with further incubation time. The inhibitory effect persisted even after preincubation with biguanides, subsequent washing of the tissue and reincubation with the substrate in a medium without

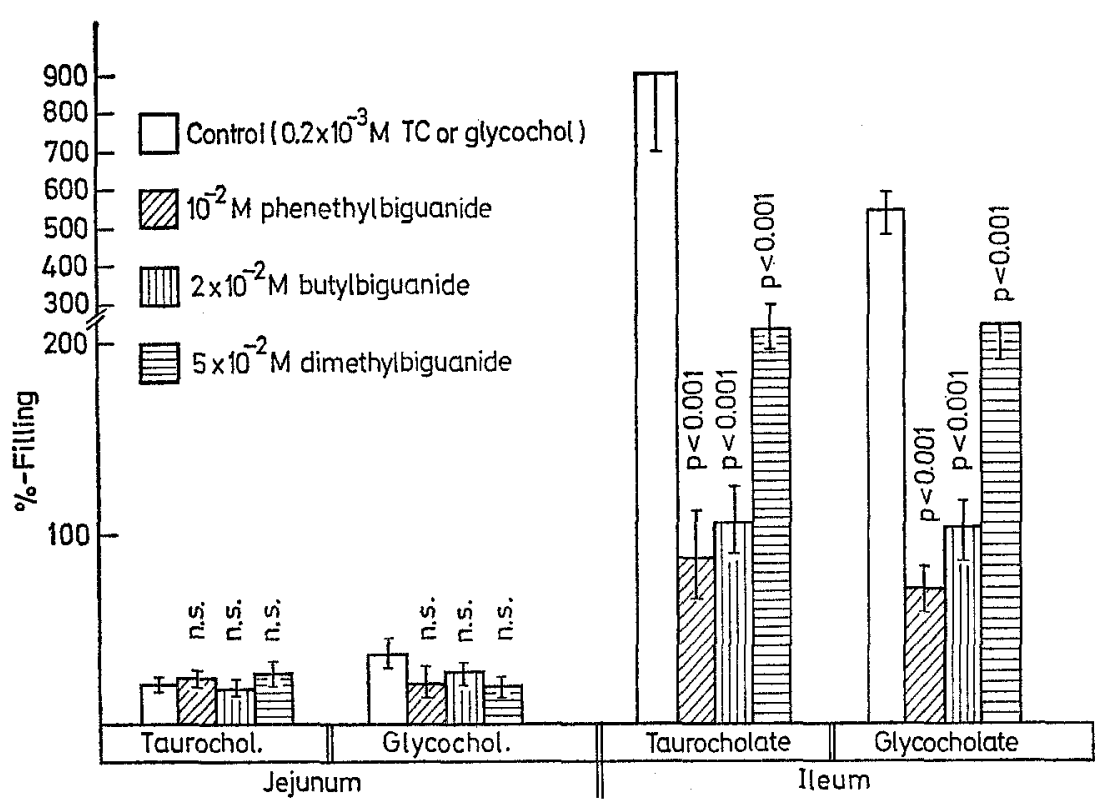

Fig. 2. Tissue uptake of bile salts in rat jejunum and ileum in the presence of biguanides. Segments of rat jejunum and ileum were incubated for $30 \mathrm{~min}$ in Krebs-Henseleit phosphate buffer with $0.2 \times 10^{-3} \mathrm{M}$ tauro- (TC) or glycocholate. Biguanides (phenethyl-, butyl- and dimethylbiguanide) were added simultaneously with the substrates. Results are means \pm SEM ( $n=6$ ) 
Table 1. Effect of preincubation with biguanides upon subsequent tissue uptake of bile salts

\begin{tabular}{lcl}
\hline Preincubation conditions & $\begin{array}{l}\text { Tissue-uptake } \\
\text { after rein- } \\
\text { cubation with } \\
0.2 \times 10^{-3} \mathrm{M} \\
\end{array}$ & $\begin{array}{l}\text { \%-in- } \\
\text { hibition } \\
\text { taurocholate }\end{array}$ \\
& $911.0 \pm 80$ & - \\
\hline Buffer & $39.5 \pm 6^{*}$ & 95.6 \\
$10^{-2}$ M Phenethylbiguanide & $65.0 \pm 8^{*}$ & 92.87 \\
$2 \times 10^{-2}$ M Butylbiguanide & $110.0 \pm 12^{*}$ & 88.0 \\
$4 \times 10^{-2}$ M Dimethylbiguanide & &
\end{tabular}

Segments of ileal rat intestine were incubated for $20 \mathrm{~min}$ under the conditions listed under 'preincubation conditions'. Tissue was then rinsed for $20 \mathrm{sec}$ with buffer and reincubated in a Krebs-Henseleit phosphate buffer medium with $0.2 \mathrm{mM}$ taurocholate in the absence of biguanides for further $20 \mathrm{~min}$. Results are means $\pm \operatorname{SEM}(n=6)$

$* p<0.001$

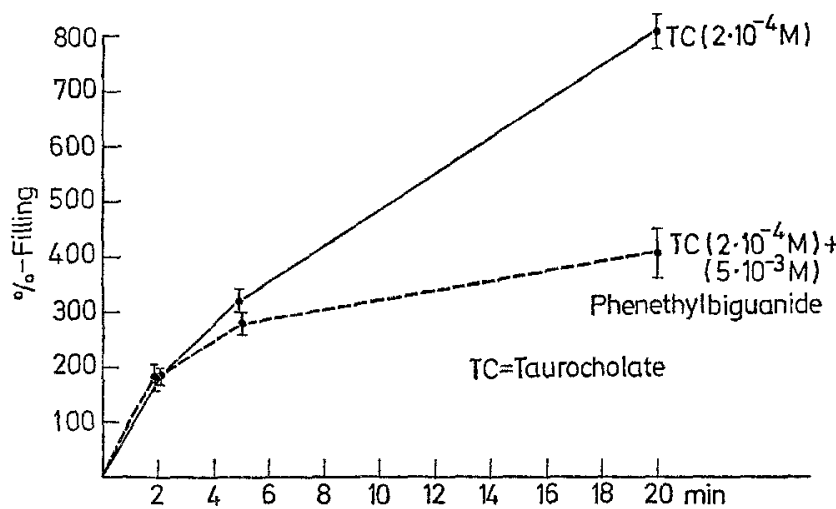

Fig. 3. Time-dependent inhibitory effect of phenethyl-biguanide upon tissue uptake of taurocholate. Tissue uptake of taurocholate by segments of rat ileum was measured in the presence of phenethyl-biguanide $\left(5 \times 10^{-3} \mathrm{M}\right)$ after 2,5 and

$20 \mathrm{~min}$ incubation. Results are means $\pm \operatorname{SEM}(n=5)$

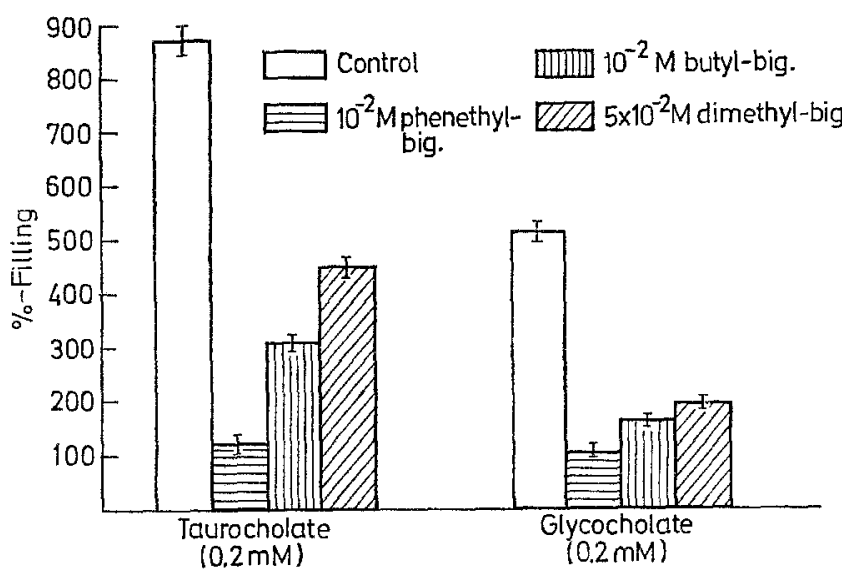

Fig. 4. Comparitive inhibitory effect of biguanides upon active transport of tauro- and glycocholate. Rat ileal segments were incubated with either $0.2 \times 10^{-3} \mathrm{M}$ taurocholate or $0.2 \times 10^{-3} \mathrm{M}$ glycocholate in the absence or presence of biguanides. Results are means $\pm \operatorname{SEM}(n=7)$ the presence of biguanides (Table 1). The inhibitory effect of biguanides upon bile salt absorption was exerted by all biguanides tested (Fig. 4). Phenethylbiguanide was a more potent inhibitor of bile salt absorption than butylbiguanide. Five to ten times higher

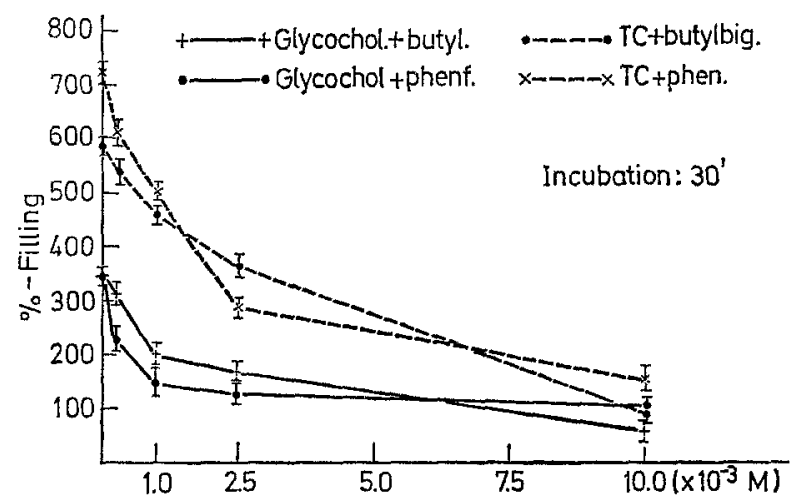

Fig. 5. Concentration-dependent inhibitory effect of phenethyl- and butylbiguanide upon transport of tauro- or glycocholate in rat ileum. Segments of rat ileal tissue were incubated with tauro- or glycocholate $\left(0.2 \times 10^{-3} \mathrm{M}\right)$ in the presence of increasing concentrations of biguanides. Incubation time $(30 \mathrm{~min})$. Results are means $\pm \operatorname{SEM}(n=5)$

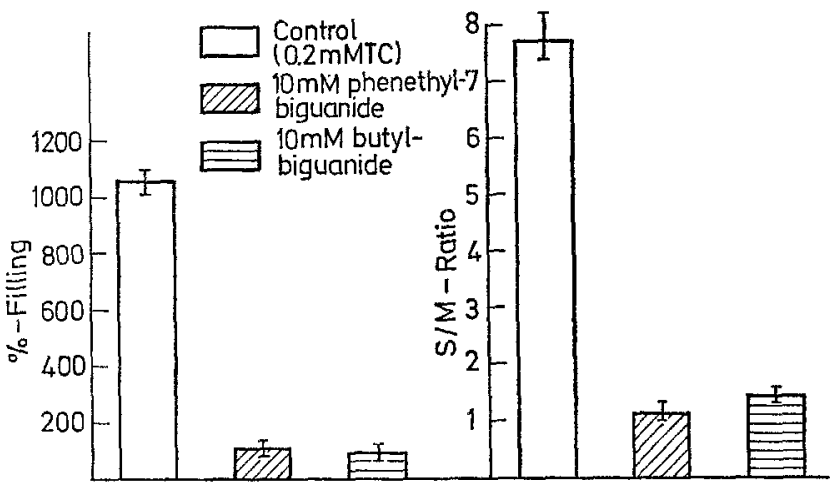

Fig. 6. Effect of biguanides upon tissue uptake and serosal accumulation of taurocholate in rat ileum. Sacs of everted rat ileum were incubated for 45 minutes in Krebs-Henseleit phosphate medium: Mucosal medium: $0.2 \times 10^{-3} \mathrm{M}$ taurocholate (TC) $\pm 10 \mathrm{mM}$ phenethyl- or butylbiguanide. Serosal medium: $0.2 \times 10^{-3} \mathrm{M}$ taurocholate. Accumulation of taurocholate in the tissue compartment of the everted sac preparation is shown on the left side, accumulation of TC in the serosal compartment on the right side of the graph. Results are means $\pm \operatorname{SEM}(\mathrm{n}=5)$

concentrations of dimethylbiguanide were required to achieve an equal inhibitory effect to phenethyl- or butylbiguanide (Fig. 4). The minimal effective inhibitory dose of phenethyl- and butylbiguanide on tissue accumulation of tauro- and glycocholate was $2.5 \times 10^{-4} \mathrm{M}$ (Fig. 5). Since the inhibitory effect increased with incubation time (Fig. 3), minimal in- 
hibitory concentrations might be even lower at longer incubation intervals.

Mucosal $\longrightarrow$ serosal transport of taurocholate was as markedly inhibited by phenethyl- and butylbiguanide as tissue uptake (Fig. 6). A decrease of serosal accumulation of taurocholate was observed by mucosal addition of biguanides (Fig. 6).

\section{Discussion}

The assumption that biguanides inhibit active transport systems in general is confirmed by this and other studies: active transport of calcium in the duodenum $[12,20]$, jejunal and ileal transport of sugars $[2,6,7,11,12,21,27,29,30,41]$ (Fig. 1) and amino acids $[7,12,20]$ as well as bile salt absorption in the ileum, whereas, diffusional transport is not affected (Fig. 2). The delayed onset of the inhibitory affect after the simultaneous introduction of substrate and inhibitor to the mucosal incubation medium and the persistence of the inhibitory effect after preincubation with biguanides and subsequent thorough washing suggests that biguanides must enter the intestinal tissue in order to exert their inhibitory effect upon active transport. The biguanide effect upon active transport systems is most likely mediated by the known inhibitory action of these antidiabetic drugs upon mitochrondrial respiration $[3,22]$. Minimal inhibitory concentrations of phenethyl- and butylbiguanide were $2.5 \times 10^{-4} \mathrm{M}$. Whether similar concentrations might be achieved in the ileum after therapeutic doses is not known. However, recent intestinal perfusion studies in man have shown that biguanides in therapeutic doses inhibited glucose absorption in man $[2,7]$. Since metformin (dimethylbiguanide) and phenformin induce $\mathrm{B}_{12}$ malabsorption $[4,5,37,38]$ and an increase of faecal weight [4] and stool frequency [31], it might be assumed that biguanides can achieve tissue concentrations in the ileum after therapeutic doses sufficient to affect bile salt reabsorption. Biguanides achieve high tissue concentrations in the small intestine even after parenteral administration [3].

The confirmation that therapeutic doses of biguanides are able to inhibit ileal reabsorption of bile salts in man could explain possibly the cholesterol-lowering effect observed during treatment of diabetics with biguanides $[3,19,25,26,32,34,35]$.

Acknowledgement. This work was supported by the Deutsche Forschungsgemeinschaft (Ca 71/2). We thank Mrs. A. Balfanz and Mrs. H. Windemth for their expert technical assistance.

\section{References}

1. Altschuld, R., Kruger, F. A.: Inhibition of gluconeogenesis in guinea pig by phenformin. Ann. N.Y. Acad. Sci. 148, 612-622 (1968)

2. Arvanitakis, C., Lorenzsonn, V., Olson, W. A.: Phenformin-induced alterations of small intestinal function and mitochondrial structure. J. Lab. clin. Med. 82, 195-200 (1973)

3. Beckmann, R.: Biguanide. In: Handbook of experimental pharmacology. (Eds. O. Eichler, A. Farah, H. Herken, A. D. Welch) Vol. XXIX, S. 439-596. Berlin: Springer-Verlag 1971

4. Berchtold, P., Bolli, P., Arbenz et al.: Intestinale Absorptionsstörung infolge Metforminbehandlung. (Zur Frage der Wirkungsweise der Biguanide). Diabetologia 5, 405412 (1969)

5. Berchtold, P., Dahlqvist, A., Gustafson, A., Asp, N. G.: Effect of a biguanide on vitamin $B_{12}$ and folic acid absorption and intestinal enzyme activities. Scand. J. Gastroent. 6, 751-754 (1971)

6. Berger, W.: Die intestinale Wirkung der Biguanide. In: W. Berger und P. Waibel: Aktuelle Probleme in der Angiologie, Band 16, 104-116. Bern-Stuttgart-Wien: Verlag Hans Huber 1971

7. Bloch, R., Menge, H., Schaarschmidt, W. D., Gottesbüren, H., Schaumlöffel, E., Goebell, H., Riecken, E. O.: Biochemische, histochemische und funktionelle Untersuchungen zur Phenforminwirkung auf die Dünndarmschleimhaut bei Ratte und Mensch. Klin. Wschr. 51, 235-241 (1973)

8. Butterfield, W. J. H., Fry, I. K., Hollnig, E.: The effect of insulin, tolbutamide and phenethylbiguanide on peripheral glucose uptake in man. Diabetes 7, 449-454 (1958)

9. Butterfield, W. J. H., Whichelow, M. J.: The hypoglycemic action of phenformin. Effect of phenformin on glucose metabolism in peripheral tissue. Diabetes 11, 281-286 (1962)

10. Caspary, W. F., Stevenson, N. R., Crane, R. K.: Evidence for an intermediate step' in carrier-mediated sugar translocation across the brush border membrane of hamster small intestine. Biochim. biophs. Acta (Amst.) 193, 168178 (1969)

11. Caspary, W. F., Creutzfeldt, W.: Analysis of the inhibitory effect of biguanides on glucose absorption: Inhibition of active sugar transport. Diabetologia 7, 379-385 (1971)

12. Caspary, W. F.: Effect of biguanides on intestinal transport of sugars, amino acids and calcium. NaunynSchmiedebergs's Arch. Pharmakol. 269, 421-422 (1971)

13. Caspary, W. F., Creutzfeldt, W.: Inhibition of intestinal amino acid transport by blood sugar lowering biguanides. Diabetologia 9, 6-12 (1973)

14. Caspary, W. F.: Increase of active transport of conjugated bile salts in streptozotocin-diabetic rat small intestine. Gut 14, 949-954 (1973)

15. Caspary, W. F.: Inhibition of active hexose and amino acid transport by conjugated bile salts in rat ileum. Europ. J. clin. Invest. 4, 17-24 (1974)

16. Connon, J. J.: A differential action of phenformin in normal and diabetic rat livers. Diabetologia 9, 47-49 (1973)

17. Cook, D. E., Blair, J. B., Lardy, H. A.: Mode of action of hypoglycemic agents. V. Studies with phenethylbiguanide in isolated perfused rat liver. J. biol. Chem. 248, 52725277 (1973) 
18. Crane, R. K., Mandelstam, P.: The active transport of sugars by various preparations of hamster small intestine. Biochim. biophys. Acta 45, 460-476 (1960)

19. Creutzfeldt, W., Appels, A., Kattermann, R., Frerichs, H., Proschek, H., Hubrich, K., Söling, H. D.: Zur Wirkung von Buformin mit und ohne Kombination von Sulfonylharnstoffen auf Gewicht und verschiedene Stoffwechselgrößen bei Diabetikern, S. 94. 2nd Intern. Biguanidsympos. Stuttgart: Thieme Verlag 1968

20. Creutzfeldt, W., Willms, B., Caspary, W. F.: The mechanism of action of blood glucose lowering biguanides. In: Diabetes. Proceedings of the VIIth Congress of the International Diabetes Federation, pp. 95-106. Buenos Aires, 1970. (Eds. R. R. Rodriguez and J. Vallance-Owen) Amsterdam: Excerpta Medica 1971

21. Czyzyk, A., Tawecki, J., Sadowski, J., Ponikowska, J., Szczepanik, Z.: Effect of biguanides on intestinal absorption of glucose. Diabetes 17, 492-498 (1968)

22. Davidoff, F.: Effect of guanidine derivatives on mitochondrial function. J. biol. Chem. 246, 4017-4027 (1971)

23. Haeckel, R.: Inhibition of glucose formation from fructose by phenformin in perfused guinea pig livers. Diabetologia 9, 161-164 (1973)

24. Holt, P. R.: Intestinal absorption of bile salts in the rat. Amer. J. Physiol. 207, 1-8 (1964)

25. Kahan, M., Hirshleifer, I., Mandel, E. E.: Serum lipids in diabetes mellitus: A comparison of the effect of tolbutamide, phenformin-hydrochloride and NPH-insulin. Diabetes 5, 536--537 (1966)

26. Kaneko, T.: Studies on the mode of action of hypoglycemic biguanides. J. Jap. Soc. int. Med. 52, 78-95 (1965)

27. Kruger, F. A., Altschuld, R. A., Hollobaugh, S. L., Jewett, B.: Studies on the site and mechanism of action of phenformin. II. Phenformin inhibition of glucose transport by rat intestine. Diabetes 19, 50-52 (1970)

28. Lack, L., Weiner, I. M.: In vitro absorption of bile salts by small intestine of rats and guinea pigs. Amer. J. Physiol. 200, 313 (1961)

29. Lorch, E.: Inhibition of intestinal absorption and improvement of oral glucose tolerance by biguanides in the nor$\mathrm{mal}$ and in the streptozotocin-diabetic rat. Diabetologia 7, 195-203 (1971)

30. Luisier, A. L., Robinson, W. L.: Inhibition of intestinal sugar and amino acid transport by $\mathrm{n}$-butyl-biguanide. In: Comparative physiology, pp. 465-475. (Eds. L. Bolis, K. Schmidt-Nielsen, S. H. P. Maddrell) Amsterdam NorthHolland Publishing Company 1973
31. Pedersen, J., Olesen, E. S.: Observations on the mechanism of increased weight loss during metformin administration in obesity. Acta endocr. (Kbh.) 57, 683 (1968)

32. Navarette, V. N., Torres, H. J., Lee, D. B., Soria, J.: Treatment with phenformin of hypercholesterolemia in hypertriglyceridemia in non-diabetic subjects. 6th Congr. Intern. Diab. Federation, Stockholm, 1967. Inter. Congr. Ser. No. 140, 45. Amsterdam: Excerpta Medica

33. Schultz, S. G., Curran, P. F.: Coupled transport of sodium and organic solutes. Physiol. Rev. 50, 637-718 (1970)

34. Schwartz, M. J., Mirsky, S., Schaefer, L. E.: Phenforminhydrochloride, serum lipids and diabetes mellitus. Diabetes 14, 465-466 (1965)

35. Schwartz, M. J., Mirshy, S., Schaefer, L. E.: The effect of phenformin-hydrochloride on serum cholesterin and triglyceride levels on the stable adult diabetes. Metabolism 15, 808-822 (1966)

36. Söling, H. D.: The effect of blood glucose lowering biguanides on liver metabolism. Acta diabetol. latina VI, Suppl. $1,656-677$ (1969)

37. Tomkin, G. H., Hadden, D. R., Weaver, J. A., Montgomery, D. A. D.: Vitamin $B_{12}$ status of patients on longterm metformin therapy. Brit. med. J. 1971 II, 685-687

38. Tomkin, G. H.: Malabsorption of vitamin $B_{12}$ in diabetic patients treated with phenformin: a comparison with metformin. Brit. med. J. 1973 II, 673-675

39. Wick, A. N., Stewart, G. J., Serif, G. S.: Tissue distribution of 14-C-labelled beta-phenethylbiguanide. Diabetes 9, $163-166(1960)$

40. Wilson, T. H., Wisemann, G.: The use of everted small intestine for the study of the transference of substances from the mucosal to the serosal surface. J. Physiol. (Lond.) 23, 116-122 (1954)

41. Wingate, D. L., Hadley, G. D.: Effect of phenformin on water and glucose transport across isolated human ileum. Diabetes 22, 175-180 (1973)

42. Yoh, Y. J.: Distribution of n-butylbiguanide-14-C-hydrochloride in mouse tissues. Jap. J. Pharmacol. 17, 439-449 (1967)

\author{
Dr. W.F. Caspary \\ Division of Gastroenterology and \\ Metabolism \\ Department of Medicine \\ University of Göttingen \\ D-34 Göttingen \\ Humboldtallee 1 \\ Federal Republic of Germany
}

